\title{
Conceptual Process Design, Energy and Economic Analysis of Solid Waste to Hydrocarbon Fuels via Thermochemical Processes
}

\author{
Hossam A. Gabbar $1, *$ (D) and Mohamed Aboughaly $2, *$ (D) \\ 1 Faculty of Energy Systems and Nuclear Science, University of Ontario Institute of Technology, \\ Oshawa, ON L1H 7K4, Canada \\ 2 Department of Chemical and Biochemical Engineering, University of Western Ontario, \\ London, ON N6A 5B9, Canada \\ * Correspondence: hossam.gaber@ontariotechu.ca (H.A.G.); mabough5@uwo.ca (M.A.)
}

Citation: A. Gabbar, H.; Aboughaly, M. Conceptual Process Design,

Energy and Economic Analysis of Solid Waste to Hydrocarbon Fuels via Thermochemical Processes. Processes 2021, 9, 2149. https://doi.org/ $10.3390 /$ pr9122149

Academic Editors: Eliseu Monteiro and Davide Papurello

Received: 18 October 2021

Accepted: 26 November 2021

Published: 28 November 2021

Publisher's Note: MDPI stays neutral with regard to jurisdictional claims in published maps and institutional affiliations.

Copyright: (c) 2021 by the authors. Licensee MDPI, Basel, Switzerland. This article is an open access article distributed under the terms and conditions of the Creative Commons Attribution (CC BY) license (https:// creativecommons.org/licenses/by/ $4.0 /)$.

\begin{abstract}
Thermochemical processes use heat and series of endothermic chemical reactions that achieve thermal cracking and convert a wide range of solid waste deposits via four thermochemical processes to hydrocarbon gaseous and liquid products such as syngas, gasoline, and diesel. The four thermochemical reactions investigated in this research article are: incineration, pyrolysis, gasification, and integrated gasification combined cycle (IGCC). The mentioned thermochemical processes are evaluated for energy recovery pathways and environmental footprint based on conceptual design and Aspen HYSYS energy simulation. This paper also provides conceptual process design for four thermochemical processes as well as process evaluation and techno-economic analysis (TEA) including energy consumption, process optimization, product yield calculations, electricity generation and expected net revenue per tonne of feedstock. The techno-economic analysis provides results for large scale thermochemical process technologies at an industrial level and key performance indicators (KPIs) including greenhouse gaseous emissions, capital and operational costs per tonne, electrical generation per tonne for the four mentioned thermochemical processes.
\end{abstract}

Keywords: techno-economic analysis (TEA); thermochemical processes; waste-to-energy (WTE); solid waste; syngas; gasoline production; diesel production; energy consumption

\section{Introduction}

Annually, global solid waste deposits exceed 2.01 billion tonnes including industrial/commercial waste, combustible and non-combustible solid waste, household waste, e-waste, composts, and solid waste generated by medical facilities [1]. In Canada, annual solid waste generation is more than 30-million tonnes per annum (Mtpa) and is expected to exceed $45 \mathrm{Mtpa}$ by 2050 [2]. Annually, global solid waste depositions exceed 2.01-billion tonnes and will reach 3-billion tonnes by 2050 at a daily carbon footprint of $0.375 \mathrm{~kg}$ per capita $[3,4]$. High income economies account for only $16 \%$ of world's population and are responsible for generation of $35 \mathrm{wt}$.\% of the annual solid waste deposits at a daily carbon footprint in developed countries is $0.74 \mathrm{~kg}$ per capital [5]. The high living standards lead the world towards an exponential increase in waste generation caused by increase in global population [6]. The high consumption and depletion of hydrocarbon fuels as well as high costs of refining have attracted attention for sustainable technologies such as hydrocarbon fuels produced from chemical conversion of solid waste deposits such as pyrolysis and gasification [7]. This manuscript main goal is to summarize the conceptual design and energy analysis of the four chemical processes as well as compare those thermochemical technologies in terms of energy consumption, yield of final products as well as economic analysis including capital and operational cost per unit.

Landfilling is considered an environmental polluting practice and contributes to a large release of methane gas in great quantities due to bioprocessing of organic materials in landfills. Countries such as Sweden imposed a landfilling tax and have eliminated 
landfilling since 2005. Landfill gas is composed of mainly $\mathrm{CO}_{2}$ and $\mathrm{CH}_{4}$ and is measured by global warming potential (GWP), whereas acidification is the sum of $\mathrm{NH}_{3}, \mathrm{NOx}$, and SOx kg-SO ${ }_{2}$ eq, and is measured by acidification potential (AP) $[8,9]$.

The global waste hierarchy for solid waste management strategies is shown in Figure 1. Strategies to reduce solid waste production are considered the most effective waste reduction strategies. The waste management key performance indicators (KPIs) are assessed based on global warming potential (GWP), acidification potential (AP), photochemical ozone creation potential (POCP), and eutrophication potential (EP) [10].

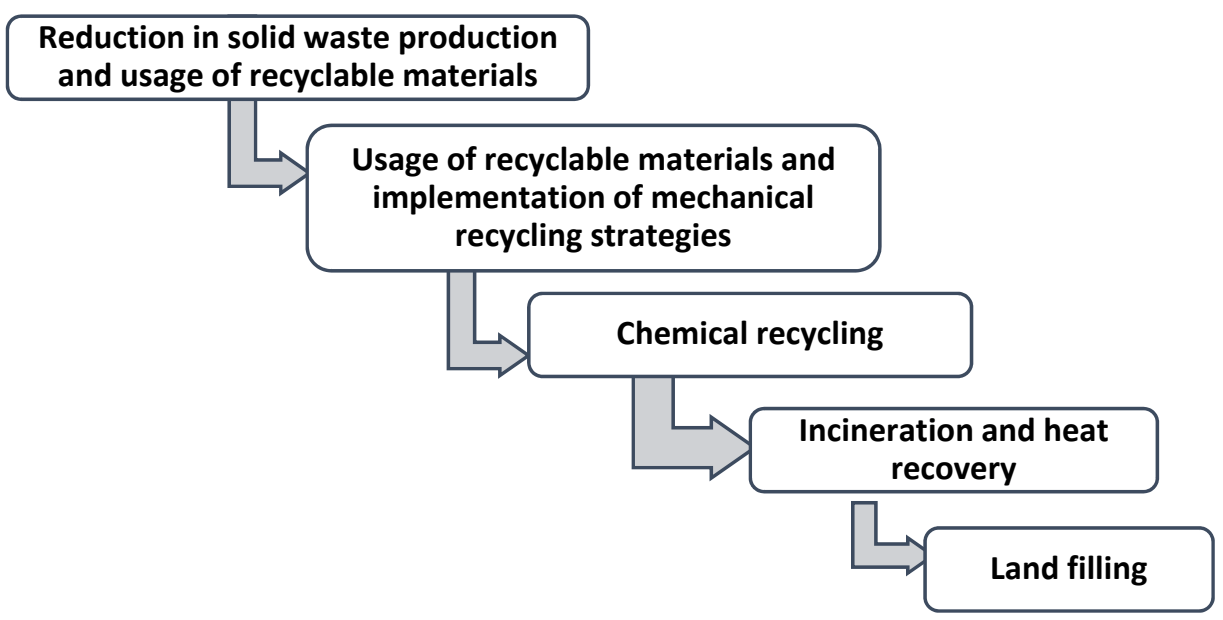

Figure 1. Recommended recycling strategies hierarchy for solid waste management.

As seen below in Figure 1, most recommended practice for solid waste management is the implementation of practice for reduction in waste generation such as usage of recyclable materials in manufacturing and usage of reusable materials. This could be achieved by the implementation of waste control strategies on industrial activities and limiting usage of plastic, paper, composts, and the implementation of internal recycling systems in manufacturing sites [11]. The second most recommended waste management strategy is solid waste mechanical recycling of paper, plastics, and composite materials to produce recyclates that substitute usage of virgin plastics. Mechanical recycling includes collection, sorting, shearing, milling, and crushing of waste to be utilized in new products [12]. The third recommended waste management strategy is thermochemical treatment processes including incineration, pyrolysis, and gasification. As a last resort, MSW landfilling is avoided due to possible soil and underground water pollution as well as high release of methane and greenhouse gaseous emissions [13]. In addition, major disadvantages of landfilling are the massive land space requirements, and the high release of landfill gas that can be $400-500 \mathrm{~m}^{3}$ / tonne of landfilled solid waste. The chemical composition of landfill gas is $50 \mathrm{wt} . \%$ methane and $50 \mathrm{wt} . \% \mathrm{CO}_{2}$. Landfilling is not recommended due to the possible breakage of buried landfills at a very slow rate as well as release of gaseous toxins, leachate, and greenhouse gases which contribute to global warming [13].

Incineration occurs in excess oxygen supply at elevated temperatures above $1000{ }^{\circ} \mathrm{C}$ yielding carbon monoxide, carbon dioxide, hydrogen, oxygen, and water vapor $\left(\mathrm{H}_{2} \mathrm{O}\right)$ [1-14]. Pyrolysis is carried in inert conditions and is the most recommended thermochemical process for conversion of solid waste to hydrocarbon liquid and gaseous fuels. Solid waste pyrolysis is the thermal cracking in inert conditions to gaseous and liquid fuels at lower operating temperatures between 450 and $700{ }^{\circ} \mathrm{C}$ in a batch process (30-60 min) time [15]. Pyrolysis is considered a highly selective thermochemical process in comparison with gasification processes and yields liquid hydrocarbon products with a higher heating value than syngas [16]. Gasification is the combustion of solid waste deposits in limited oxygen supply into gaseous products at high temperatures using gasification agents such as oxygen, air, or steam [17-19]. Air is a common gasification agent, cheap and convenient; 
however, the nitrogen content reduces the overall calorific value of the producer gas and overall energy efficiency of the gasification process $[20,21]$.

Syngas produced from pyrolysis and gasification could be upgraded to liquid hydrocarbon fuels via the Fischer-Tropsch chemical process [22]. Fischer-Tropsch processes use catalytic transition metals including iron, cobalt, and nickel to convert syngas to liquid hydrocarbon fuels, which have a higher market value and can be used as combustible fuels in ignition engines [23]. Iron based catalysts, transition metals such as cobalt, iron, and ruthenium are used to favor methane formation [23]. Integrated gasification combined cycles use high pressure pyrolysis and gasification reaction systems in series to convert solid waste deposits to syngas and hydrocarbon fuels. Removal of impurities prior to the combustion process is advised to lower emissions of sulfur dioxide and prevent corrosion of gas turbines [24].

The thermodynamic efficiency in integrated combined gasification cycles could be improved by excess heat integration from primary combustion and syngas combustion systems with the steam cycle system, which results in higher thermodynamic efficiency compared to conventional gasification cycles [21-24]. The Claus process is used to desulfurize and eliminate syngas impurities prior syngas turbine to reduce gaseous emissions during combustion including sulfur dioxide, particulates, mercury, and carbon dioxide [24,25].

\section{Conceptual Design and Process Description of Thermochemical Processes}

Thermochemical technologies provide a reaction pathway for conversion of solid waste to a range of hydrocarbon liquid and gaseous fuels. This study provides a comparison of thermochemical technologies and recommendations in terms of economics, fuel generation, energy consumption, and electrical efficiency. Below are the expected environmental emissions flowrates in ( $\mathrm{kg} /$ tonne of product gas) as shown in Table 1.

Table 1. Solid waste thermochemical reactions gaseous emissions ( $\mathrm{kg} /$ tonne of product gas) [8,26-30].

\begin{tabular}{ccccc}
\hline $\begin{array}{c}\text { Thermochemical } \\
\text { Process }\end{array}$ & $\left.\begin{array}{c}\text { Nitrogen } \\
\text { Oxides (NO }\end{array}\right)$ & SO $_{\mathbf{x}}$ & $\mathbf{C O}$ & $\mathbf{H C l}$ \\
\hline $\begin{array}{c}\text { Combined } \\
\text { Pyrolysis-gasification }\end{array}$ & $1.96 \times 10^{-1}$ & $2.81 \times 10^{-2}$ & $2.81 \times 10^{-2}$ & $5.62 \times 10^{-3}$ \\
\hline Solid Waste Pyrolysis & $7.80 \times 10^{-1}$ & $1.96 \times 10^{-1}$ & $1.96 \times 10^{-1}$ & $3.90 \times 10^{-3}$ \\
\hline $\begin{array}{c}\text { Solid Waste } \\
\text { Gasification }\end{array}$ & $4.50 \times 10^{-1}$ & $1.40 \times 10^{-1}$ & $1.40 \times 10^{-1}$ & $1.70 \times 10^{-2}$ \\
\hline
\end{tabular}

In incineration, solid waste is combusted in oxygen supply at atmospheric pressure while in gasification, solid waste is combusted in partial oxidation at a stoichiometric ratio (air to fuel ratio, $\mathrm{k}=0.5-0.8$ ), to produce syngas, thermal energy, and tar. Since air contains nitrogen, effluents from solid waste incineration include nitrous oxides $\left(\mathrm{N}_{2} \mathrm{O}\right.$ and $\mathrm{NO}_{\mathrm{x}}$ ) [13-15]. Incineration releases the highest $\mathrm{CO}_{2}$ emissions and has the high operational cost and pollutes the environment due to ash waste. Gasification releases less $\mathrm{CO}$ and $\mathrm{CO}_{2}$ but forms other toxic gases such as dioxins, furans, sulfur oxides, and nitrous oxides [31,32]. Below are the following simultaneous reactions that occur in both heterogeneous and homogenous phases during solid waste gasification include the following [1,16].

\subsection{Thermochemical Processes Chain Reactions}

\subsubsection{Solid Waste Pyrolysis Chain Reactions}

$2 \mathrm{C}+\mathrm{O}_{2} \rightarrow 2 \mathrm{CO}-110 \mathrm{MJ} / \mathrm{mol}$ Incomplete combustion

$2 \mathrm{CO}+\mathrm{O}_{2} \rightarrow 2 \mathrm{CO}_{2}-280 \mathrm{MJ} / \mathrm{mol}$ Complete combustion of $\mathrm{CO}$

$\mathrm{C}+\mathrm{O}_{2} \rightarrow \mathrm{CO}_{2}-392 \mathrm{MJ} / \mathrm{mol}$ Complete Oxidation

$\mathrm{H}_{2}+\frac{1}{2} \mathrm{O}_{2} \rightarrow \mathrm{H}_{2} \mathrm{O}-240 \mathrm{MJ} / \mathrm{mol}$ Hydrogen combustion

$2 \mathrm{C}_{\mathrm{n}} \mathrm{H}_{\mathrm{m}}+\mathrm{nO}_{2} \rightarrow \mathrm{nCO}+\mathrm{m} \mathrm{H}_{2}$ Exothermic reaction $\mathrm{C}_{\mathrm{n}} \mathrm{H}_{\mathrm{m}}$ incomplete oxidation 


\subsubsection{Solid Waste Gasification Chain Reactions}

$\mathrm{C}+\mathrm{H}_{2} \mathrm{O} \rightarrow \mathrm{CO}+\mathrm{H}_{2} 130 \mathrm{MJ} / \mathrm{Kmol}$ Redox reaction

$\mathrm{CO}+\mathrm{H}_{2} \mathrm{O} \rightarrow \mathrm{CO}_{2}+\mathrm{H}_{2} 41 \mathrm{MJ} / \mathrm{Kmol}$ Water-gas reaction

$\mathrm{CH}_{4}+\mathrm{H}_{2} \mathrm{O} \rightarrow \mathrm{CO}+3 \mathrm{H}_{2}+206 \mathrm{MJ} / \mathrm{Kmol}$ Steam and methane reformation

$\mathrm{C}_{\mathrm{n}} \mathrm{H}_{\mathrm{m}}+\mathrm{nH}_{2} \mathrm{O} \rightarrow \mathrm{CO}+3 \mathrm{H}_{2}$ Endothermic Steam reformation

2.1.3. Solid Waste Gasification Chain Reactions with Carbon Dioxide

$\mathrm{C}+\mathrm{CO}_{2} \rightarrow 2 \mathrm{CO}+172 \mathrm{MJ} / \mathrm{kmol}$ Boudouard reaction

$\mathrm{C}_{\mathrm{n}} \mathrm{H}_{\mathrm{m}}+\mathrm{nCO}_{2} \rightarrow 2 \mathrm{nCO}+{ }_{\mathrm{m} / 2} \mathrm{H}_{2}$ Endothermic Reforming

2.1.4. Tar and Hydrocarbons Decomposition Reactions

$\mathrm{pC}_{\mathrm{x}} \mathrm{H}_{\mathrm{y}} \rightarrow \mathrm{qC}_{\mathrm{n}} \mathrm{H}_{\mathrm{m}}+\mathrm{rH}_{2}$ Hydrogenation

$\mathrm{C}_{\mathrm{n}} \mathrm{H}_{\mathrm{m}} \rightarrow \mathrm{nC}+{ }_{\mathrm{m} / 2} \mathrm{H}_{2}$ Carbonization

\subsection{Thermochemical Reactions Process Block Diagrams (PBD)}

The chemical process flow diagrams for thermochemical reaction systems are illustrated in this section. The presented process flow diagrams provide basic structure of main process units s shown below.

\subsubsection{Incineration Process}

Incineration converts combustible solid waste in a complete oxidation reaction at high temperatures to $\mathrm{CO}_{2}, \mathrm{CO}$, and methane at $850-1100^{\circ} \mathrm{C}$ [16]. The final products: ash, flue gas, and thermal energy. The process block diagram of solid waste incinerators is shown below in Figure 2.

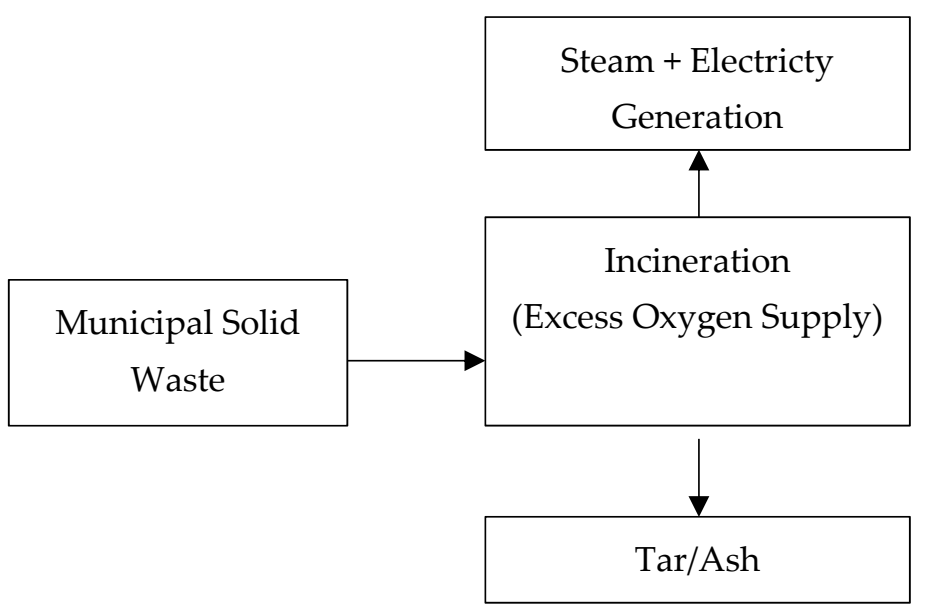

Figure 2. Incineration process system.

\subsubsection{Solid Waste Gasification Process System}

Solid waste gasification is combustion of solid waste deposits in limited oxygen supply ( $<30 \mathrm{wt}$. \% oxygen) to carbon monoxide $(\mathrm{CO})$, hydrogen $\left(\mathrm{H}_{2}\right)$, and methane $\left(\mathrm{CH}_{4}\right)$. Solid waste gasification is a common chemical technology recommended for electricity and power generation through combustion of syngas using oxygen or steam [16]. The process block diagram is shown below in Figure 3 as below. 


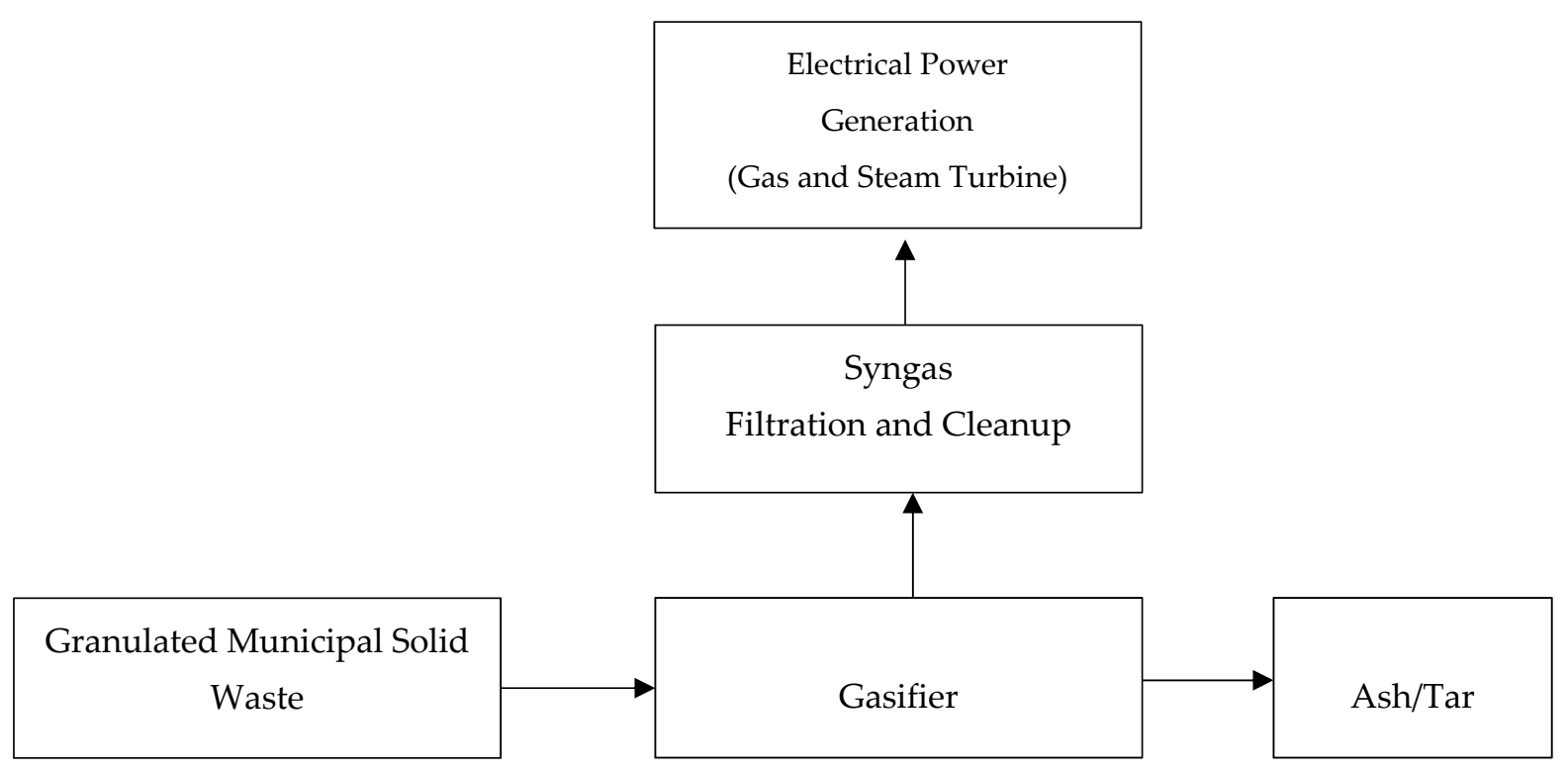

Figure 3. Solid waste gasification process.

Globally, there are more than 100 sites for solid waste gasification systems. The operating conditions are $1100{ }^{\circ} \mathrm{C}<30-40 \mathrm{wt} . \% \mathrm{O}_{2}$ at atmospheric pressure), short residence time (i.e., continuous process), and high conversion in comparison with pyrolysis and incineration. The solid waste feedstock is crushed to increase the surface area which speeds up the thermochemical process and prevent hot spots. The moisture content and oxygen concentration are controlled during the gasification process [33].

\subsubsection{Solid Waste Pyrolysis Process System}

Solid waste pyrolysis is either conventional, fast, or flash pyrolysis process depending on heating rate, residence time and operating temperature. Conventional pyrolysis has a long residence time and slow heating rates (up to $10-30{ }^{\circ} \mathrm{C} / \mathrm{min}$ ) and rate, residence time are recommended for production of liquid hydrocarbon products. Fast pyrolysis has higher heat flux in comparison with conventional pyrolysis and yields more gaseous products than conventional pyrolysis. The process block diagram of pyrolysis process is shown below in Figure 4.

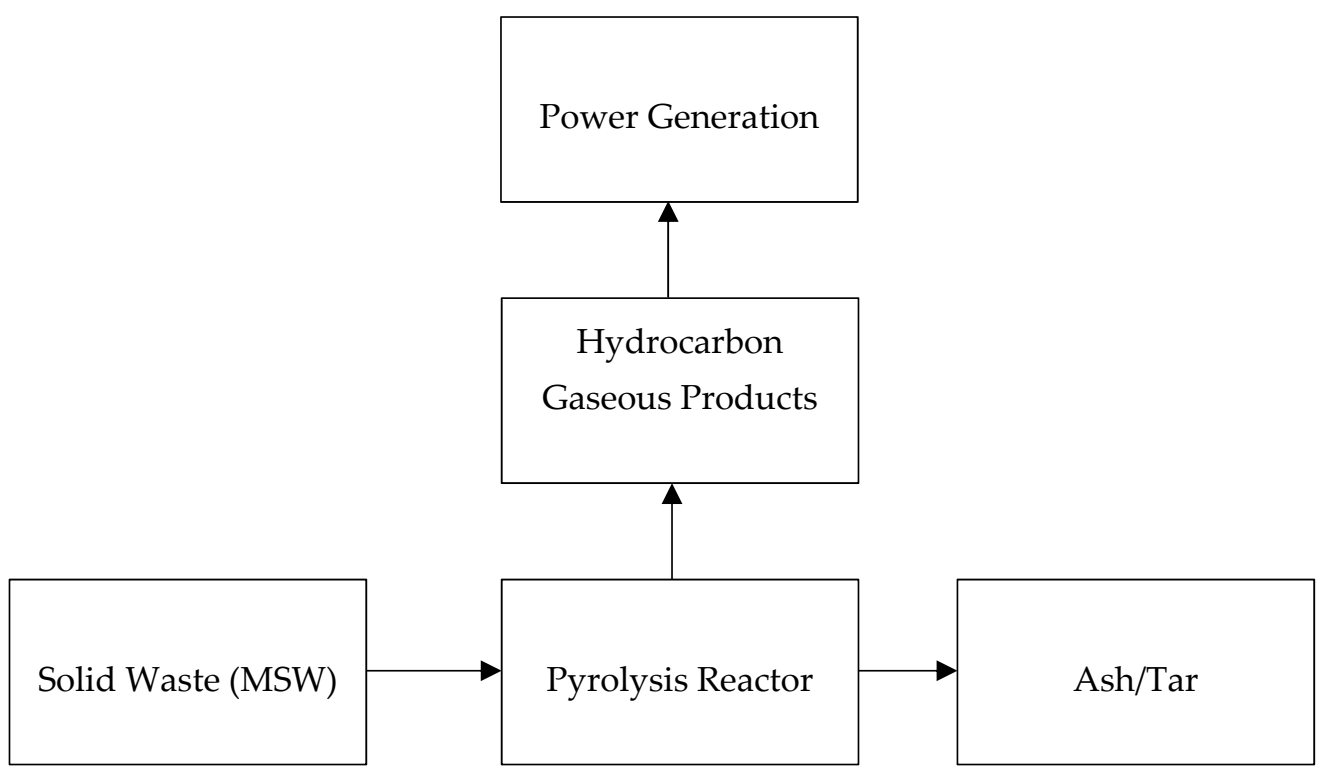

Figure 4. Solid waste pyrolysis process. 
The operating temperature is higher than slow pyrolysis (i.e., $850{ }^{\circ} \mathrm{C}$ ). Lastly, flash pyrolysis has the highest operating temperature compared to fast pyrolysis as shown in Table 2. Fast and flash pyrolysis are considered continuous reactions and have higher gaseous product yields than slow pyrolysis while the latter has the highest liquid product yield [34-36]. Solid waste pyrolysis operating parameters vary based on heating rate, pyrolysis temperature, reaction residence time, and is divided into three classifications as shown in Table 2 as below.

Table 2. Main operating conditions for MSW pyrolysis process.

\begin{tabular}{cccc}
\hline Parameters & $\begin{array}{c}\text { Conventional Pyrolysis } \\
\text { (Slow Pyrolysis) }\end{array}$ & Fast Pyrolysis & Flash Pyrolysis \\
\hline $\begin{array}{c}\text { Operating } \\
\text { temperature }\left({ }^{\circ} \mathrm{C}\right)\end{array}$ & $550-900$ & $850-1250$ & $900-1300$ \\
\hline Heat flux $\left({ }^{\circ} \mathrm{C} / \mathrm{s}\right)$ & $0.1-1$ & $10-200$ & $>1000$ \\
\hline$\tau(\mathrm{s})$ & $300-3600$ & $0.5-10$ & $<0.5$ \\
\hline
\end{tabular}

\subsection{Thermochemical Reactions Kinetic Models}

The kinetic models used for modelling of solid waste pyrolysis process are shown in Table 3. Below are the following kinetic models used in Aspen HYSYS simulation and techno-economic assessment to estimate the conversion yield and final products that occur in both heterogenous and homogenous reaction phases during pyrolysis process. Table 4 illustrates the kinetic models used in pyrolysis process systems as below.

Table 3. Solid waste pyrolysis kinetic models [15].

\begin{tabular}{ccc}
\hline Reference & Pyrolysis Models & Properties \\
\hline$[36]$ & $\begin{array}{c}-\rho \mathrm{c} \frac{\delta \mathrm{T}}{\delta \mathrm{t}}+\rho \mathrm{vc} \frac{\delta \mathrm{T}}{\delta \mathrm{t}}=\frac{\delta}{\delta \mathrm{x}}\left(\lambda \times \frac{\delta \mathrm{T}}{\delta \mathrm{x}}\right) \\
\text { Where the regression rate }(1 / \mathrm{s}) \mathrm{v} \\
-\mathrm{v}=\mathrm{B} \times \exp \left(-\frac{\mathrm{E}}{\mathrm{RT}}\right)\end{array}$ & $\begin{array}{c}\text { Pre-exponential factor } \mathrm{B} \text {, heat of } \\
\text { evaporation } \mathrm{L} \text {, required activation } \\
\text { energy E, universal gas constant } \mathrm{R}, \\
\text { and reaction temperature } \mathrm{T}_{\mathrm{s}}\end{array}$ \\
\hline [37] & $-\rho c_{p} \frac{\delta \mathrm{T} \prime}{\delta \mathrm{t}^{\prime}}+\mathrm{H}, \mathrm{m}=\frac{\partial}{\partial z}\left(\lambda \times \frac{\partial T z}{\partial z}\right)$ & $\begin{array}{c}\text { Pre-exponential factor } \mathrm{B} \text {, heat of } \\
\text { vaporization } \mathrm{H}_{\mathrm{V}} \text {, activation energy } \\
\text { E, and reaction temperature } \mathrm{T}_{\mathrm{z}}\end{array}$ \\
\hline
\end{tabular}

Table 4. Economic analysis of MSW treatment methods in USD/ton of MSW feedstock [27].

\begin{tabular}{ccccc}
\hline Parameter & $\begin{array}{c}\text { Incineration } \\
\text { (USD/ton) }\end{array}$ & $\begin{array}{c}\text { Pyrolysis } \\
\text { (USD/ton) }\end{array}$ & $\begin{array}{c}\text { Pyrolysis } \\
\text { /Gasification (P-G) } \\
\text { (USD/ton) }\end{array}$ & $\begin{array}{c}\text { Gasification } \\
\text { (USD/ton) }\end{array}$ \\
\hline $\begin{array}{c}\text { Capital } \\
\text { Investment }\end{array}$ & 231,995 & 173,873 & 205,186 & 160,675 \\
\hline O\&M Cost & 16,433 & 143,874 & 15,422 & 13,743 \\
\hline Revenue & -6400 & 400 & 300 & 62,000 \\
\hline
\end{tabular}

\section{Conceptual Design and Process Flow Diagram of Thermochemical Reactions}

As seen below in Figure 5, MSW is shredded using MSW granulator, which helps to increase heat transfer area of waste, reduces feedstock volume, increases wastes homogeneity, and avoid agglomeration [37]. The MSW waste is dried to prevent heat losses due to existence of moisture in MSW feedstock. The shredded refuse derived fuel (RDF) is then added to the pyrolysis reactor, which operates at atmospheric pressure and $500{ }^{\circ} \mathrm{C}$ releasing hydrocarbon gases and oils. The pyrolysis reactor consists of a heat exchanger network for steam generation as well as recycling cyclone that improves saturation and increases reflux before sending gaseous streams to the hydrocarbon condenser. The distillation column 
separates gasoline and diesel content using fractional distillation and pumps hydrocarbons to storage tanks.

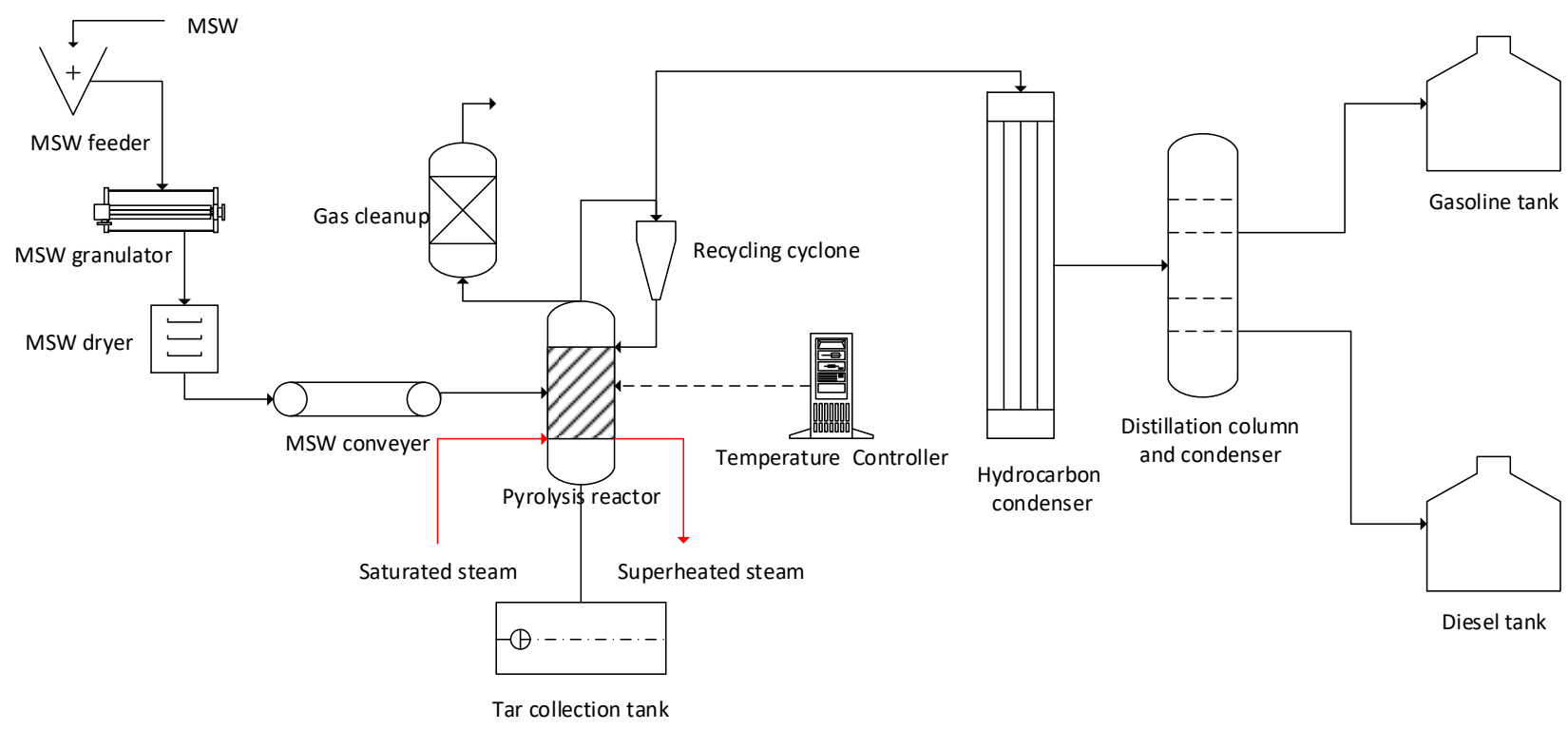

Figure 5. Process flow diagram of solid waste pyrolysis plant.

As seen below in Figure 6, MSW is granulated and dried before entering the gasifier through a conveying system, which reduces the volume of municipal solid waste volume by one-fifth [38]. The municipal solid waste is gasified at temperatures higher than $600{ }^{\circ} \mathrm{C}$ depending on the waste characteristics [39]. The gaseous products from the gasifier passes through $\mathrm{H}_{2} \mathrm{~S}$ scrubber and $\mathrm{CO}$ shift reactor. $\mathrm{H}_{2} \mathrm{~S}$ is chemically adsorbed from syngas in zinc-oxide catalyst beds [40]. The $\mathrm{CO}$ shift reactor further converts $\mathrm{CO}$ to $\mathrm{CO}_{2}$ and $\mathrm{H}_{2}$ in an exothermic reaction under iron-based catalysts [41]. Both reactors reduce greenhouse gaseous emissions and hydrogen sulfide emissions to the atmosphere. The syngas is combusted allowing high thermal energy gases to enter the syngas turbine where the exhaust gases are also utilized for steam and electricity generation. A typical syngas turbine consists of an air compressor, combustion system (i.e., which produces a high temperature and high-pressure turbine gas that feeds the gas turbine) and a gas turbine that generates electricity.

As seen below in Figure 7, a typical incineration system consists of an incinerator where the reaction residence time is more than one second and operating temperature above $1000{ }^{\circ} \mathrm{C}$ that ensures complete combustion in excess oxygen [42]. A typical incinerator consists of three zones, namely, a drying zone, an oxidation zone, and a combustion zone. Steam is generated through thermal energy and combustion of gaseous effluents. The gaseous effluents pass through a dry scrubber before entering the gas turbine to prevent air pollution to the atmosphere. Landfilling is also defined as disposal of non-hazardous compacted solid waste for final disposal. Landfill gas (LFG) is a natural byproduct of organic decomposition of solid waste organic components. Landfill gas is mainly composed of $50 \mathrm{wt} . \% \mathrm{CO}_{2}$ and $50 \mathrm{wt} . \%$ methane gas $\left(\mathrm{CH}_{4}\right)$. A typical process flow diagram of a solid waste landfilling chemical plant is shown below in Figure 8. 


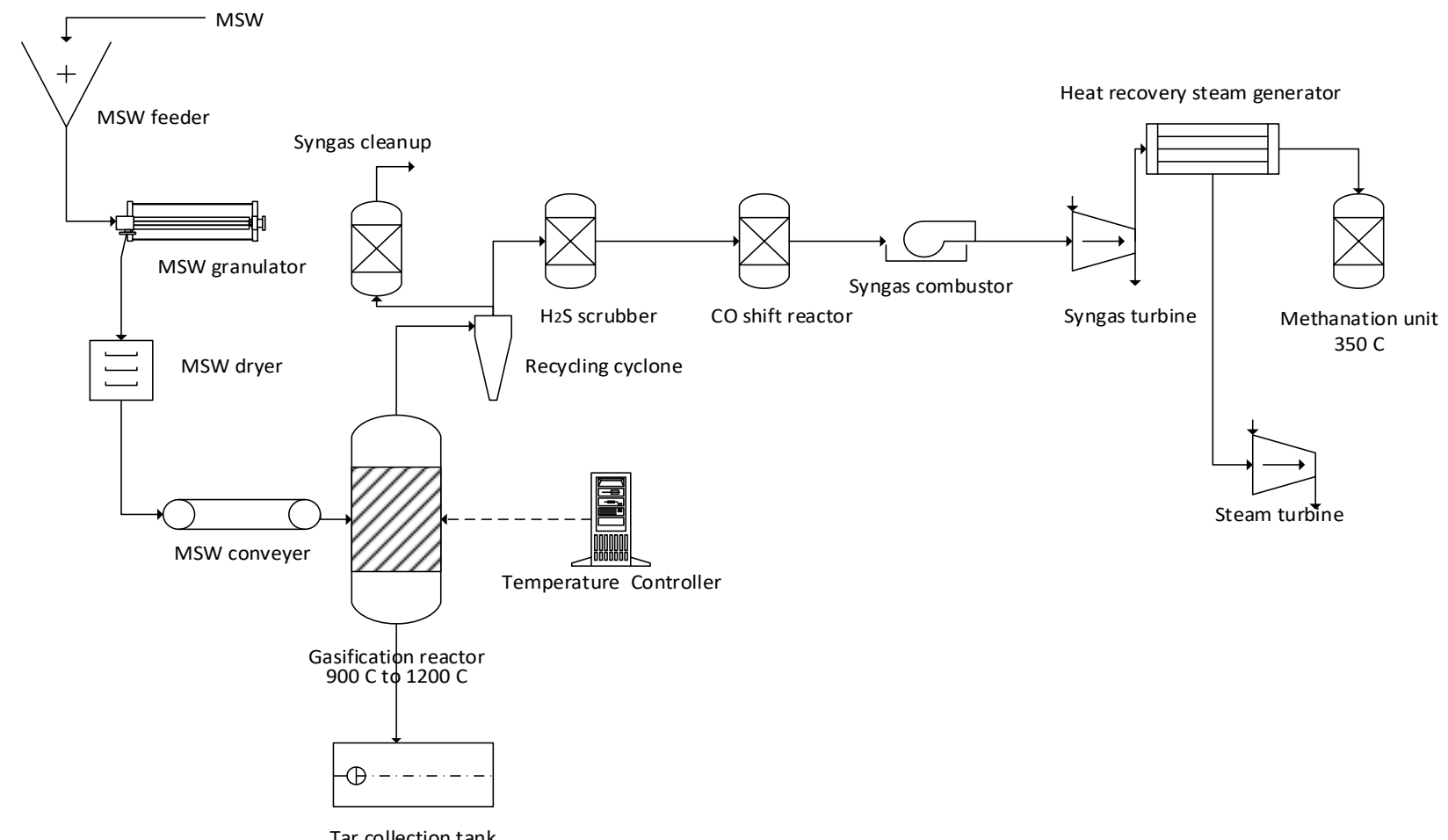

Figure 6. Process flow diagram of solid waste gasification plant.

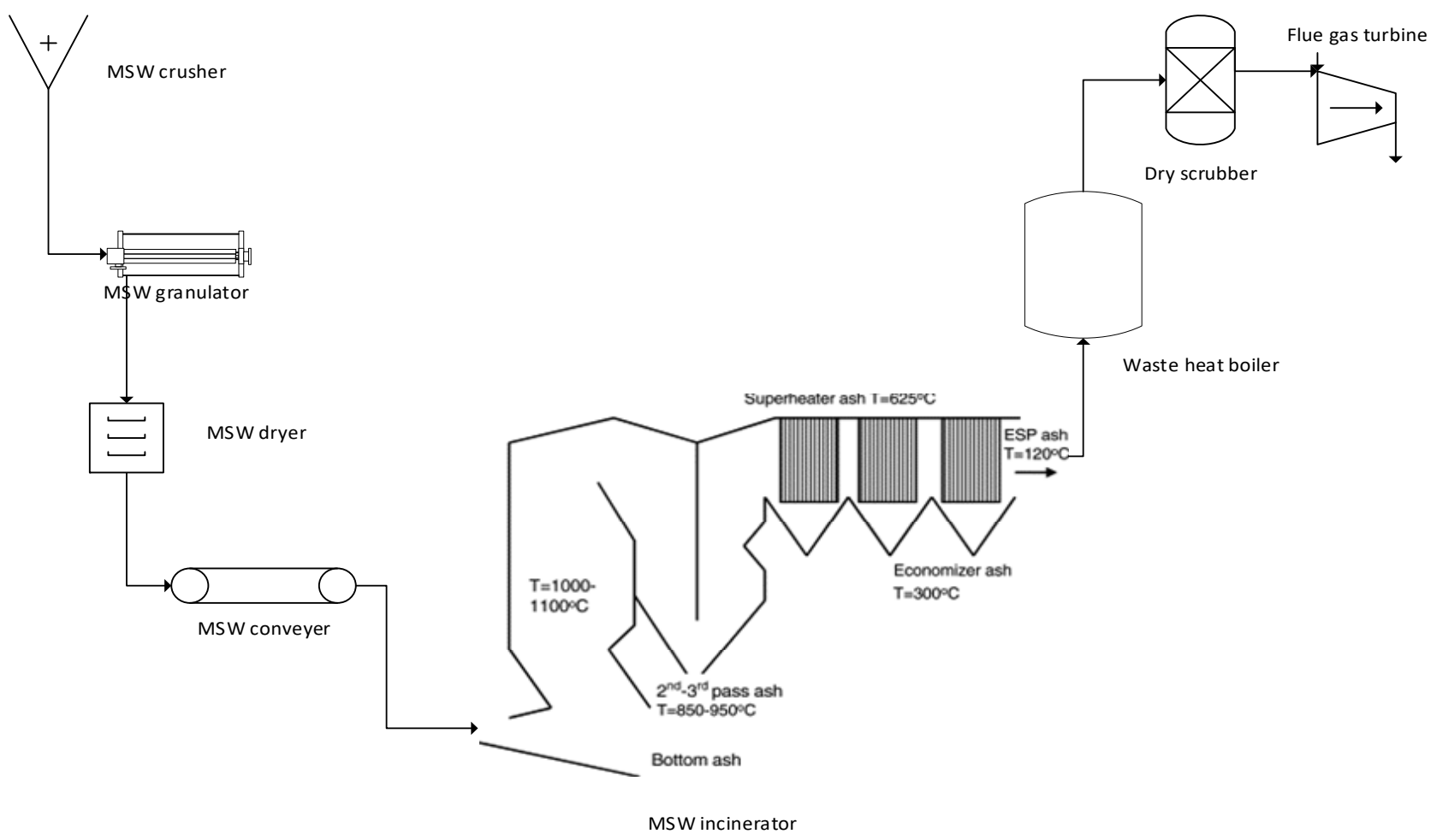

Figure 7. Process flow diagram of solid waste incineration plant. 


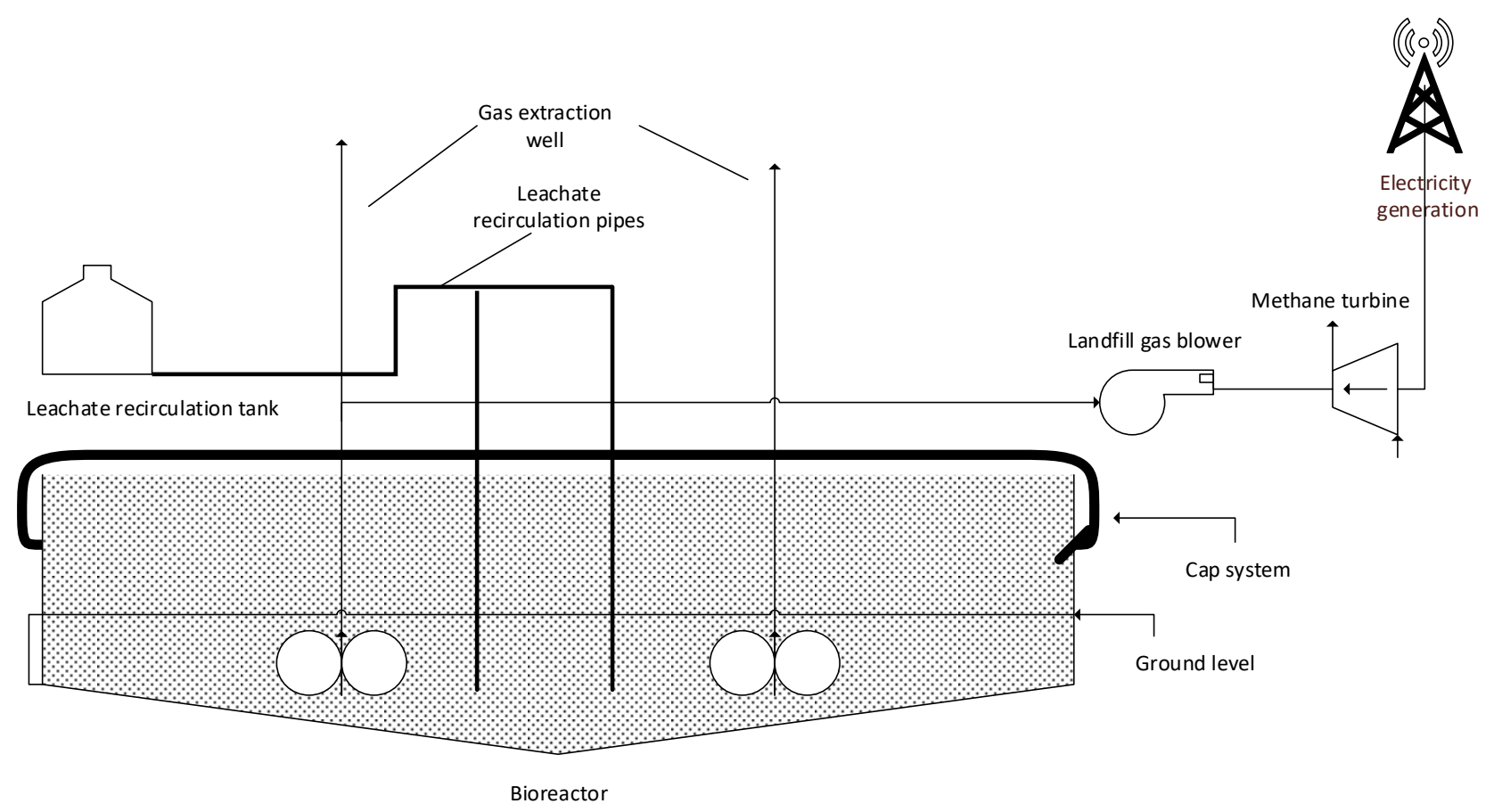

Figure 8. Process flow diagram of solid waste landfilling pilot plant.

\section{Energy Analysis of Solid Waste Thermochemical Reactions}

Municipal solid waste feedstock possesses many challenges, such as varying of feedstock composition in different geographical regions. Moreover, the moisture content in solid waste feedstock could exceed $75 \mathrm{wt} . \%$ and require further treatment to avoid consuming high amount of energy in heating or drying steps [43-46]. Average energy required for solid waste granulation is 3 to $50 \mathrm{KW}$ with expected bulk density of shredded solid waste $25-50 \mathrm{~kg} / \mathrm{m}^{3}$. Grinding equipment varies and includes mincers, crushers, cutters, millers, and shredders.

The grinding process involves a variety of operations using equipment such as mincer, crushers, cutters, mills, grinders, shredders, disintegrators, and homogenizers [2,3]. Grinding requires the breaking or tearing of the materials by such mechanisms as compression, impact, attrition, or shear and cutting [4]. The second stage in any industrial thermochemical process is preheating of solid waste deposits to elevated temperatures to avoid agglomeration and reduce content of undesired products. The preheating stage elevates solid waste deposits to around $150-200{ }^{\circ} \mathrm{C}$ depending on the melting point of the solid waste mixture. The expected energy required for preheating $7-45 \mathrm{MJ} / \mathrm{kg}$ depending on the solid waste feedstock.

\section{Techno-Economic Assessment of Thermochemical Processes}

An economic analysis is conducted on the four different thermochemical processes at an industrial scale of 500 tonnes per day (TPD). The techno-economic assessment is a method to analyze the economic performance of industrial processes using software modelling to estimate the expected capital, operational costs, and revenues based on history of previous chemical plants financial and technical inputs. The techno-economic analysis includes economic feasibility, research and development, as well as study of uncertainty and risk assessment [1].

As shown below in Table 5, the capital investment per ton is calculated using detailed equipment of existing chemical plants used for detailed design and estimation of costs based on different plant sizes as adopted from [47]. The following cost estimation methods are used in economic analysis as shown in Table 5 using the six-tenth power method using the equations as below in Equation (1) [48]. 
Table 5. Common CAPEX and OPEX costs in chemical plants.

\begin{tabular}{cc}
\hline CAPEX Costs & OPEX Costs \\
\hline Chemical and Engineering Equipment & Electricity Usage \\
\hline Utility equipment & Operational and labor costs \\
\hline Engineering costs & Maintenance materials and spare parts \\
\hline Equipment start-up costs & Administration costs \\
\hline General facilities costs such as offices & Research and development costs \\
\hline
\end{tabular}

The cost estimation methods used for economic analysis in Table 5 use processes:

$$
\frac{\$ B}{\$ A}=\left(\frac{\operatorname{Cap} B}{\operatorname{Cap} A}\right)^{0.6}
$$

The capital cost, operating and maintenance cost $(\mathrm{O} \& M)$, and revenue are calculated as shown below in Table 4.

As seen above in Table 5, average data for capital, operating cost and revenue is assessed for several thermochemical plants with different sizes. The results show that incineration requires the highest capital cost and is $13 \%$ and $44 \%$ higher compared to pyrolysis and gasification, respectively. The investment (CAPEX) investment is defined as a capital investment endured by a business for the future, whereas an operating and maintenance cost (OPEX) is an expense required for day-to-day business requirements [1,49].

The high capital cost of incineration plants is justified by restricted environmental design and environmental emission regulations. Incineration plants require cost upgrades including particulate matter removal, semi-dry and wet scrubbers for acidic gases, selective non-catalytic and catalytic reduction in nitrous oxides (NOx), and activated carbon (AC) technology for removal of dioxins and heavy metals [46-51]. The equipment installed to reduce greenhouse gaseous emissions are considered CAPEX, whereas day to day operational equipment such as filters and removal of acidity in effluent gases are considered OPEX. Below are list of common CAPEX and OPEX costs as shown in Table 5.

The techno-economic analysis includes a technological side and an economic side with different analyzer parameters and methods. The data flow and used approach used for techno-economic analysis is illustrated in Figure 9 as below.

Gasification shows the lowest capital cost investment per tonne followed by pyrolysis process. In terms of operating and maintenance ( $\mathrm{O} \& \mathrm{M}$ cost) pyrolysis requires tar removal equipment as well as high condensation costs. In terms of revenue, gasification has 200 times higher the revenue in comparison with alternative thermal treatment methods [52]. In terms of capital cost, it increases exponentially with capacity. Below are expected capital costs from 100 to 3000 tons per day for incineration and gasification plants as shown below in Table 6 .

As seen above in Table 7, an exponential increase is shown for both incineration and gasification plants. Incineration has the highest capital cost followed by gasification and pyrolysis. Incineration chemical plants require NOx and SOx combustors to ensure complete combustion and reduce overall harmful emissions. Moreover, activated carbon (AC) is used to remove chlorine, particles, and volatile organic compounds (VOC) from gaseous effluents [50,53]. 


\section{Technological side}

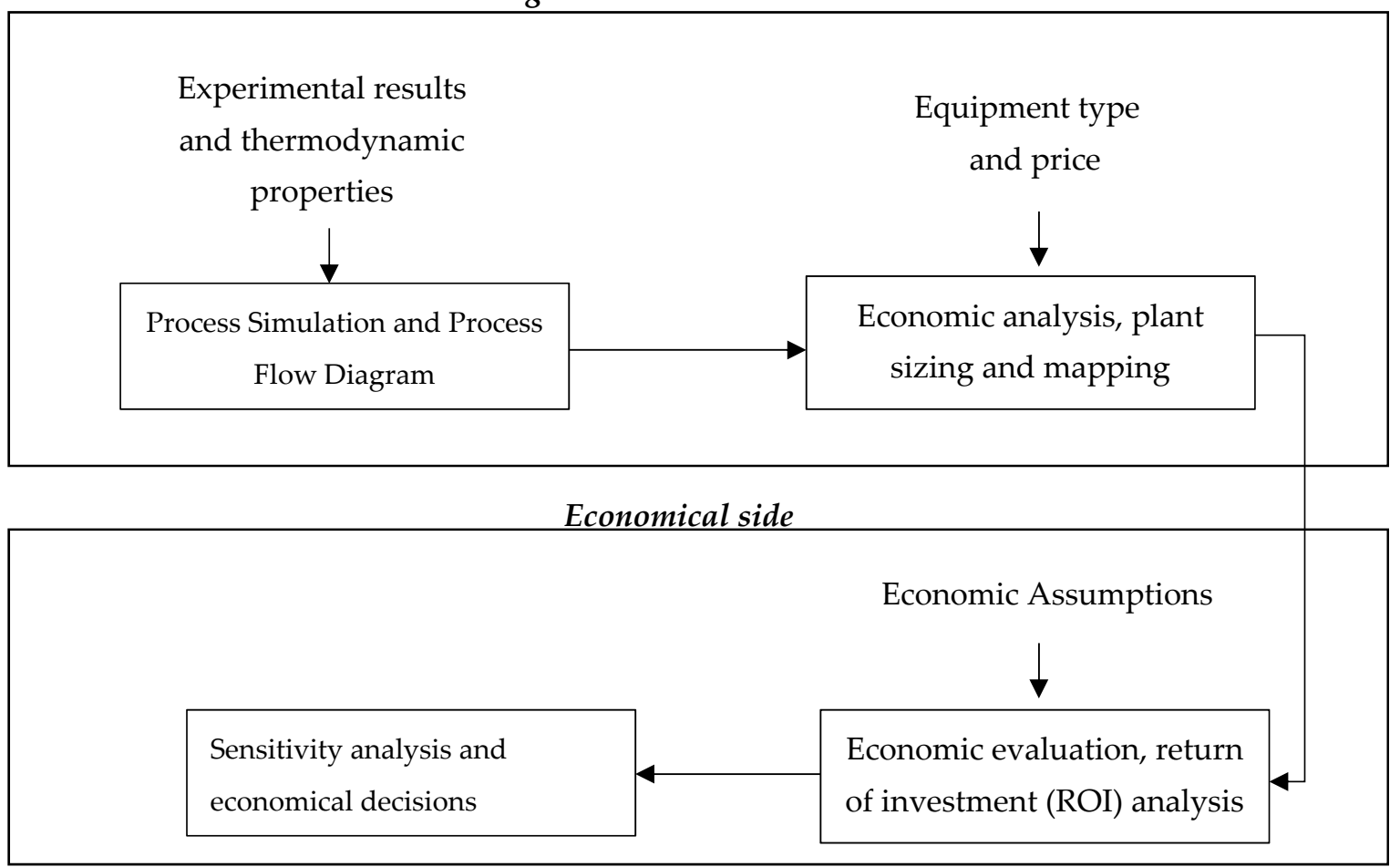

Figure 9. Techno-economic analysis (TEA) approach flow diagram.

Table 6. Capital cost and plant capacity per ton for incineration and gasification plants [8].

\begin{tabular}{ccccccc}
\hline Plant Type & \multicolumn{3}{c}{ Incineration } & \multicolumn{3}{c}{ Gasification } \\
\hline Capacity (tons/Day) & 1000 & 2000 & 3000 & 1000 & 2000 & 3000 \\
\hline Capital Cost (USD Million) & 100 & 170 & 300 & 55 & 110 & 180 \\
\hline
\end{tabular}

Table 7. Estimated Energy consumption per kWh based economic analysis [49].

\begin{tabular}{ccc}
\hline Thermochemical Process & $\begin{array}{c}\text { Energy Required for } \\
\text { Start-Up (kWh) }\end{array}$ & $\begin{array}{c}\text { Residual/Solid Waste for } \\
\text { DISPOSAL (kg) }\end{array}$ \\
\hline Pyrolysis-gasification (P-G) & 300 & 19.55 \\
\hline Pyrolysis & 200 & 90.13 \\
\hline Thermal cracking gasification & 12 & 18.02 \\
\hline
\end{tabular}

As seen below, gasification shows the lowest start-up energy. Combined pyrolysis and gasification (P-G) show highest energy consumption due to two reaction systems and higher start-up energy consumption as shown below in Table 7. In terms of MSW residue, pyrolysis shows highest and tar production.

The net electrical and thermal efficiency varies for each WTE plant depending on the capacity and process design. The process efficiency is measured in the reactor while the thermal efficiency and electrical is measured in the gas turbine and steam turbine.

Below are the expected net energy recovery efficiencies of different WTE methods. As seen below, incineration and pyrolysis show highest thermal efficiency. Pyrolysis shows lower electrical efficiency and is only recommended to convert solid waste deposits to hydrocarbon liquids. Gasification and incineration are recommended for electricity generation. Below are electrical and heat efficiencies of thermochemical processes as shown in Table 8. 
Table 8. Thermal and electrical efficiencies for WTE methods based Aspen HYSYS simulation [16].

\begin{tabular}{cccc}
\hline $\begin{array}{c}\text { Thermochemical } \\
\text { Process }\end{array}$ & $\begin{array}{c}\text { Gross Electricity } \\
\text { Efficiency }\end{array}$ & $\begin{array}{c}\text { Net Electricity } \\
\text { Efficiency }\end{array}$ & Net Heat Efficiency \\
\hline Incineration & $0-34$ & $2-30$ & $0-87$ \\
\hline Gasification & $33-34$ & 34 & $26-40$ \\
\hline Pyrolysis & 18 & 15.25 & 70 \\
\hline $\begin{array}{c}\text { Combined } \\
\text { Pyrolysis-gasification }\end{array}$ & 35 & 32 & 40 \\
\hline
\end{tabular}

The thermal efficiency of a WTE thermal plant is controlled mainly by the following aspects:

- The maximum temperature in the steam turbine is limited to reduce corrosion and formation of acids in major equipment such as boilers and steam turbines.

- The superheated steam maximum temperature is controlled to reduce the system pressure and avoid entrained liquids and damage to steam turbine blades

- The turbine isentropic efficiency is limited by steam mass flow rate and reduces with modest power output.

\section{Conclusions}

In conclusion, the gasification and combined (P-G) process achieves the highest electrical efficiency and the highest process integration. Incineration has shown the highest thermal efficiency and is recommended for district heating. Pyrolysis is most recommended for production of liquid hydrocarbon fuels. Pyrolysis has the highest ROI due to the high value of liquid hydrocarbon fuels. For large scale chemical plants, incineration shows the highest capital investment due to environmental considerations and highest greenhouse gaseous emissions followed by combined pyrolysis and gasification (P-G) and pyrolysis. Gasification process has the lowest capital investment and provides the highest yield of gaseous products. In terms of energy consumption, combined pyrolysis-gasification chemical plants have 25 times higher energy consumption than conventional gasification. Highest electrical efficiency is achieved by gasification followed by the combined pyrolysis and gasification $(\mathrm{P}-\mathrm{G})$ process. The combined pyrolysis and gasification $(\mathrm{P}-\mathrm{G})$ process also requires the highest startup electrical efficiency while solid waste pyrolysis yields the highest residual solid waste for disposal. Future research will include the integration of different chemical processes to achieve a higher yield of hydrocarbon gaseous and liquid products to reduce emissions and increase product yields of important fuels such as gasoline and diesel. Moreover, future research that includes further study of the Fischer-Tropsch processes upgrading the quality of hydrocarbon gaseous and liquid products is recommended.

Author Contributions: Conceptualization, methodology, validation, Supervision and guidelines for original manuscript are provided by H.A.G., Conceptual process design, methodology and manuscript designed and written by M.A. All authors have read and agreed to the published version of the manuscript.

Funding: Funding is provided by Proflange Ltd., 130 Vondrau Dr, Cambridge, ON N3E $1 B 8$.

Institutional Review Board Statement: Not applicable.

Informed Consent Statement: Not applicable.

Data Availability Statement: Not applicable.

Conflicts of Interest: The authors declare no conflict of interest. 


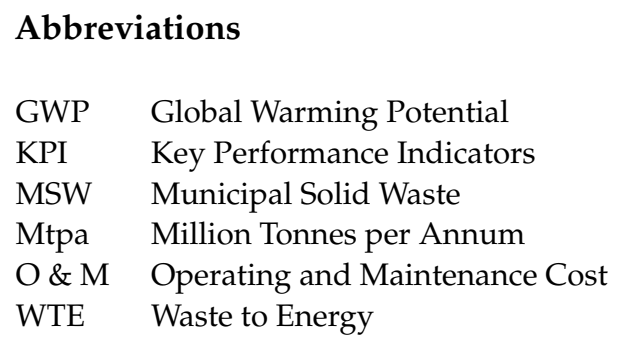

\section{References}

1. The World Bank. Trends in Solid Waste Management; The World Bank: Washington, DC, USA, 2020.

2. Environment Canada. Technical Document on Municipal Solid Waste Organics Processing; Minister of the Environment: Gatineau, QC, Canada, 2013.

3. Rhyner, C.R.; Schwartz, L.J.; Wenger, R.B.; Kohrell, M.G. Waste Generation. In Waste Management and Resource Recovery; CRC Press: Boca Raton, FL, USA, 2018. [CrossRef]

4. Kawai, K.; Tasaki, T. Revisiting estimates of municipal solid waste generation per capita and their reliability. J. Mater. Cycles Waste Manag. 2016, 18, 1-13. [CrossRef]

5. Moustakas, K. Decision Maker's Guide to Municipal Solid Waste Incineration. In Waste Management, 2nd ed.; Kumar, E.S., Ed.; InTechopen: London, UK, 2015. Available online: https:/ / www.cambridge.org/core/books/abs/climate-change-2014-impactsadaptation-and-vulnerability-part-b-regional-aspects/ocean/38C1BED42EBBDB07470534A27FE0FA5F (accessed on 17 October 2021). [CrossRef]

6. Rajaeifar, M.A.; Ghanavati, H.; Dashti, B.B.; Heijungs, R.; Aghbashlo, M.; Tabatabaei, M. Electricity generation and GHG emission reduction potentials through different municipal solid waste management technologies: A comparative review. Renew. Sustain. Energy Rev. 2017, 79, 414-439. [CrossRef]

7. Matsakas, L.; Gao, Q.; Jansson, S.; Rova, U.; Christakopoulos, P. Green conversion of municipal solid wastes into fuels and chemicals. Electron. J. Biotechnol. 2017, 26, 69-83. [CrossRef]

8. Anshassi, M.; Sackles, H.; Townsend, T.G. A review of LCA assumptions impacting whether landfilling or incineration results in less greenhouse gas emissions. Resour. Conserv. Recycl. 2021, 174, 105810. [CrossRef]

9. Assamoi, B.; Lawryshyn, Y. The environmental comparison of landfilling vs. incineration of MSW accounting for waste diversion. Waste Manag. 2012, 32, 1019-1030. [CrossRef] [PubMed]

10. Vaish, B.; Sharma, B.; Srivastava, V.; Singh, P.; Ibrahim, M.H.; Singh, R.P. Energy recovery potential and environmental impact of gasification for municipal solid waste. Biofuels 2019, 10, 87-100. [CrossRef]

11. Miertus, S.; Ren, X. Environmentally Degradable Plastics and ICS-UNIDO Global Program. In Biodegradable Polymers and Plastics; Springer Nature: Gewerbestrasse, Switzerland, 2003. [CrossRef]

12. Luijsterburg, B.; Goossens, H. Assessment of plastic packaging waste: Material origin, methods, properties. Resour. Conserv. Recycl. 2014, 85, 88-97. [CrossRef]

13. Manfredi, S.; Tonini, D.; Christensen, T.H.; Scharff, H. Landfilling of waste: Accounting of greenhouse gases and global warming contributions. Waste Manag. Res. 2009, 27, 825-836. [CrossRef]

14. Sharma, K.D.; Jain, S. Municipal solid waste generation, composition, and management: The global scenario. Soc. Responsib. J. 2020, 16, 917-948. [CrossRef]

15. Pranoto, P.; Himawanto, D.A.; Arifin, N.A. The influence of composition and final pyrolysis temperature variations on global kinetics of combustion of segregated municipal solid waste. IOP Conf. Ser. Mater. Sci. Eng. 2017, 193, 012044. [CrossRef]

16. Gabbar, H.A.; Aboughaly, M.; Ayoub, N. Comparative study of MSW heat treatment processes and electricity generation. $J$. Energy Inst. 2017, 91, 481-488. [CrossRef]

17. Ozturk, M.; Dincer, I. Integrated Gasification Combined Cycles. In Comprehensive Energy Systems; Elsevier: Amsterdam, The Netherlands, 2018; Volume 4-5. [CrossRef]

18. Zhang, Y.; Cui, Y.; Chen, P.; Liu, S.; Zhou, N.; Ding, K.; Fan, L.; Peng, P.; Min, M.; Cheng, Y.; et al. Gasification technologies and their energy potentials. In Sustainable Resource Recovery and Zero Waste Approaches; Elsevier: Amsterdam, The Netherlands, 2019. [CrossRef]

19. Rasul, M.G.; Begum, S. Energy recovery from solid waste: Application of gasification technology. In Handbook of Ecomaterials; Springer: Berlin, Germany, 2019; Volume 2. [CrossRef]

20. Zhang, Q. Mathematical Modeling of Municipal Solid Waste Plasma Gasification in a Fixed-Bed Melting Reactor; KTH Royal Institute of Technology: Stockholm, Sweden, 2011.

21. Xu, P.; Jin, Y.; Cheng, Y. Thermodynamic Analysis of the Gasification of Municipal Solid Waste. Engineering 2017, 3, 3. [CrossRef]

22. Čespiva, J.; Skřínský, J.; Vereš, J.; Borovec, K.; Wnukowski, M. Solid-recovered fuel to liquid conversion using fixed bed gasification technology and a Fischer-Tropsch synthesis unit-Case study. Int. J. Energy Prod. Manag. 2020, 5, 3. [CrossRef]

23. Speight, J.G. Fischer-Tropsch Process. In Handbook of Gasification Technology; Wiley: Hoboken, NJ, USA, 2020. [CrossRef]

24. Frey, H.C.; Zhu, Y. Improved system integration for integrated gasification combined cycle (IGCC) systems. Environ. Sci. Technol. 2006, 40, 5. [CrossRef] 
25. Speight, J.G. Handbook of Gasification Technology: Science, Processes, and Applications; Wiley-Scrivener: Hoboken, NJ, USA, 2017; Volume 110.

26. Chhabra, V.; Shastri, Y.; Bhattacharya, S. Kinetics of Pyrolysis of Mixed Municipal Solid Waste-A Review. Procedia Environ. Sci. 2016, 35, 513-527. [CrossRef]

27. Young, G.C. How Can Plasma Arc Gasification Take Garbage to Liquid Fuels and Case Studies? In Municipal Solid Waste to Energy Conversion Processes: Economic, Technical, and Renewable Comparisons; Wiley: Hoboken, NJ, USA, 2010; Chapter 3.

28. Bovea, M.D.; Ibáñez-Forés, V.; Gallardo, A.; Colomer-Mendoza, F.J. Environmental assessment of alternative municipal solid waste management strategies. A Spanish case study. Waste Manag. 2010, 30, 2383-2395. [CrossRef]

29. Saheri, S.; Aghajani, M.; Basri, N.E.A.; Mahmod, N.Z.B.; Begum, R.A. Environmental assessment of municipal solid waste disposal options in Malaysia. Aust. J. Basic Appl. Sci. 2011, 5, 11.

30. Ramos, A.; Teixeira, C.A.; Rouboa, A. Environmental assessment of municipal solid waste by two-stage plasma gasification. Energies 2019, 12, 137. [CrossRef]

31. Maya, D.M.Y.; Sarmiento, A.L.E.; de Sales Oliveira, C.A.V.B.; Lora, E.E.S.; Andrade, R. Gasification of Municipal Solid Waste for Power Generation in Brazil, a Review of Available Technologies and Their Environmental Benefits. J. Chem. Chem. Eng. 2016, 10, 6. [CrossRef]

32. Gent, S.; Twedt, M.; Gerometta, C.; Almberg, E. Introduction to Thermochemical Conversion Processes. In Theoretical and Applied Aspects of Biomass Torrefaction; Elsevier: Amsterdam, The Netherlands, 2017. [CrossRef]

33. Panepinto, D.; Blengini, G.A.; Genon, G. Economic and environmental comparison between two scenarios of waste management: MBT vs thermal treatment. Resour. Conserv. Recycl. 2015, 97, 16-23. [CrossRef]

34. Mashkin, N.A.; Bartenjeva, E.A. Foamer Influence on the Foam Concrete Properties Obtained in the High-Speed Foam Generator. Mater. Sci. Forum 2016, 870, 163-168. [CrossRef]

35. Chen, D.; Yin, L.; Wang, H. Pyrolysis technologies for municipal solid waste. Waste Manag. 2014, 34, 2466-2486. [CrossRef] [PubMed]

36. Gomez, E.; Rani, D.A.; Cheeseman, C.R.; Deegan, D.; Wise, M.; Boccaccini, A.R. Thermal plasma technology for the treatment of wastes: A critical review. J. Hazard. Mater. 2009, 161, 614-626. [CrossRef]

37. Pichtel, J. Recycling Solid Wastes. In Waste Management Practices; CRC Press: Boca Raton, FL, USA, 2014. [CrossRef]

38. Kwak, T.H.; Lee, S.; Park, J.W.; Maken, S.; Yoo, Y.D.; Lee, S.H. Gasification of municipal solid waste in a pilot plant and its impact on environment. Korean J. Chem. Eng. 2006, 23, 954-960. [CrossRef]

39. Arena, U. Process and technological aspects of municipal solid waste gasification. A review. Waste Manag. 2012, 32, 625-639. [CrossRef]

40. Gu, Q.; Wu, W.; Jin, B.; Zhou, Z. Analyses for synthesis gas from municipal solid waste gasification under medium temperatures. Processes 2020, 8, 84. [CrossRef]

41. Mehariya, S.; Iovine, A.; Casella, P.; Musmarra, D.; Figoli, A.; Marino, T.; Sharma, N.; Molino, A. Fischer-Tropsch synthesis of syngas to liquid hydrocarbons. In Lignocellulosic Biomass to Liquid Biofuels; Elsevier: Amsterdam, The Netherlands, 2019. [CrossRef]

42. Cheremisinoff, P.N. Handbook of Water and Wastewater Treatment Technology; Elsevier: Amsterdam, The Netherlands, 2019. [CrossRef]

43. Dong, J.; Chi, Y.; Tang, Y.; Ni, M.; Nzihou, A.; Weiss-Hortala, E.; Huang, Q. Effect of Operating Parameters and Moisture Content on Municipal Solid Waste Pyrolysis and Gasification. Energy Fuels 2016, 30, 3994-4001. [CrossRef]

44. Paode, R.D.; Liu, J.I.; Holsen, T.M. Modeling the Energy Content of Municipal Solid Waste Using Multiple Regression Analysis. J. Air Waste Manag. Assoc. 1996, 46, 650-656. [CrossRef]

45. Qiao, Y. Pyrolysis Characteristics and Kinetics of Typical Municipal Solid Waste Components and Their Mixture: Analytical TG-FTIR Stud. Energy Fuels 2018, 32, 10801-10812. [CrossRef]

46. Wang, L.; Lei, H.; Liu, J.; Bu, Q. Thermal decomposition behavior and kinetics for pyrolysis and catalytic pyrolysis of Douglas fir. RSC Adv. 2018, 8, 2196-2202. [CrossRef]

47. Perry, D.G.R. Perrys Chemical Engineerings' Handbook; McGraw-Hill Education: New York, NY, USA, 2008.

48. Shabani, M.R.; Yekta, R.B. Suitable method for capital cost estimation in chemical processes industries. Cost Eng. 2006, 48, 22.

49. Tcholbanoglous, G.; Kreith, F. Handbook of Solid Waste Management, 2nd ed.; McGraw-Hill Education: New York, NY, USA, 2002.

50. Kim, J.; Jeong, S. Economic and environmental cost analysis of incineration and recovery alternatives for flammable industrial waste: The case of South Korea. Sustainability 2017, 9, 1638. [CrossRef]

51. Makarichi, L.; Jutidamrongphan, W.; Techato, K. The evolution of waste-to-energy incineration: A review. Renew. Sustain. Energy Rev. 2018, 91, 812-821. [CrossRef]

52. Young, G.C. Plasma Economics: Garbage/Wastes to Power, Case Study with Economics of a 94 ton/day Facility. In Municipal Solid Waste to Energy Conversion Processes: Economic, Technical, and Renewable Comparisons; Wiley: Hoboken, NJ, USA, 2010 ; Chapter 7.

53. van der Vaart, D.R.; Vatavuk, W.M.; Wehe, A.H. The Estimation of Thermal and Catalytic Incinerators for the Control of VOCs. J. Air Waste Manag. Assoc. 1991, 41, 497-501. [CrossRef] 